
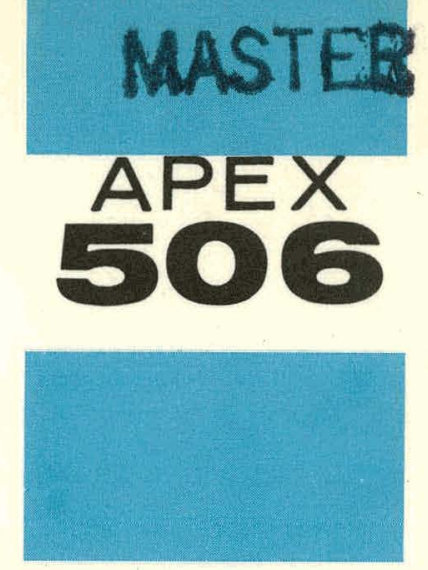

\title{
A NEW STANDARDIZATION TECHNIQUE FOR X-RAY ABSORPTION MEASUREMENTS
}

\author{
J.O. HIBBITS, S.S.COOPER, M.R.MENKE
}

\section{GENERAL gLECTRIC ATOMIC PRODUCTS DIVISION}

AIRCRAFT NUCLEAR PROPULSION DEPARTMENT

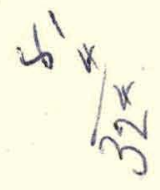




\section{DISCLAIMER}

This report was prepared as an account of work sponsored by an agency of the United States Government. Neither the United States Government nor any agency Thereof, nor any of their employees, makes any warranty, express or implied, or assumes any legal liability or responsibility for the accuracy, completeness, or usefulness of any information, apparatus, product, or process disclosed, or represents that its use would not infringe privately owned rights. Reference herein to any specific commercial product, process, or service by trade name, trademark, manufacturer, or otherwise does not necessarily constitute or imply its endorsement, recommendation, or favoring by the United States Government or any agency thereof. The views and opinions of authors expressed herein do not necessarily state or reflect those of the United States Government or any agency thereof. 


\section{DISCLAIMER}

Portions of this document may be illegible in electronic image products. Images are produced from the best available original document. 


\section{LEGAL NOTICE}

This report was prepared as an account of Government sponsored work. Neither the United States, nor the Commission, nor the Air Force, nor any person acting on behalf of the Commission or the Air Force:

A. Makes any warranty or representation, express or implied, with respect to the accuracy, com. pleteness, or usetulness of the information contained in this report, or that the use of any information, apparatus, method, or process disclosed in this report may not infringe privately owned rights; or

B. Assumes any liabilities with respect to the use of, or for damages resulting from the use of any information, apparatus, method, or process disclosed in this report.

As used in the above "person acting on behalf of the Commission or Air Force" includes any employee or contractor of the Commission or Air Force to the extent that such employee or contractor prepares, handles, or distributes, or provides access to, any information pursuant to his employment or contract with the Commission or Air Force.

Printed in USA. Price 50 venls. Available from the

Office of Technical Services

U.S. Department of Commerce

Washington 25, D.C. 


\title{
A New Standardization Technique for X-Ray Absorprion Measurements
}

\author{
J. O. Hibbits, S. S. Cooper, M. R. Menke
}

Applied Materials Research Sub-Section

United States Air Force

United States Atomic Energy Commission
Contract No. AF 33(600)-38062

Contract No. AT (11-1)-171

\author{
GENERAL ELECTRIC \\ ATOMIC PRODUCTS DIVISION \\ AIRCRAFT NUCLEAR PROPULSION DEPARTMENT \\ Cincinnati 15 , Ohio \\ Published by \\ Technical Publications Sub-Section \\ August 1959
}




\begin{abstract}
Tests of previously suggested methods of determining uranium in solution by X-ray absorption indicated that daily calibration of the $\mathrm{X}$-ray photometer is necessary because of changes in response. It has been found that by using machined aluminum plates as standards rather than uranium solutions, the time necessary for daily calibration can be reduced to about 15 minutes. The method has been found to have a limit of error of \pm 0.25 percent at the 95 percent confidence level for a single determination of uranium in a solution equivalent to about 30 milligrams uranium dioxide per gram of solution. It was found difficult to obtain cells matched for X-ray absorption work, a point that has been insufficiently stressed in the past.
\end{abstract}




\section{A New Standardization Technique for $X$-Ray Absorption Measurements}

\section{INTRODUCTION}

Analyses by X-ray absorption measurements are rapid and nondestructive, although nonspecific. The latter difficulty becomes relatively unimportant when the desired constituent is of considerably higher atomic number than other elements present. Advantages in this respect can also be gained by a judicious choice of tube voltage. For example, lead in the presence of cadmium can be determined with considerably more accuracy at 25 peak kilovolts than at 75 peak kilovolts where the two elements give nearly the same absorption. This effect is caused by "absorption edges" in the absorption spectra of the elements. Lambert ${ }^{3}$ has presented a detailed study of the absorption of $\mathrm{X}$ rays as a function of atomic number and source voltage.

The determination of uranium in the presence of small amounts of impurities, such as aluminum or iron, which would interfere in the conventional potentiometric or gravimetric methods for uranium, furnishes an excellent opportunity for the application of the X-ray absorption technique. Other applications of X-ray absorption to analysis include the determination of lead in gasoline, $1,5,6$ sulfur in hydrocarbons, 6 and chlorine in plastics. ${ }^{4}$

\section{APPARATUS}

A General Electric Model SO-4E351 G1 X-ray photometer was employed. This instrument, having a General Electric FS source with CSI25 tube (45 peak kilovolts), is similar to that described by Lambert. ${ }^{3}$ It is a split-beam instrument using polychromatic radiation, one beam passing through a cell containing a solution of the sample in question and the other beam attenuated by a circular aluminum wedge and passing through a similar cell containing the reference solvent. Both beams pass to separate ion chambers. The difference in current output of the two ion chambers is amplified sufficiently to be measured easily by a microammeter. The aluminum attenuator wedge can be rotated to bring the current difference to zero. The angular position of the aluminum wedge can be measured by means of a vernier dial, and the dial reading is then a function of the absorbance of the unknown solution.

The sample cells and holder are shown in Figure 1. The cells are 1-centimeter Pyrex cylinders with Corex windows. Pyrex arms have been sealed to the cells to prevent leakage during use. Two brass plates with machined holes are placed above the sample and the reference solutions to prevent absorption by the cell side walls. The aluminum plates used in this study are also shown in Figure 1. The pipette shown in the illustration was used to add solutions to the cells.

\section{EXPERIMENTAL PROCEDURE}

\section{Preparation of Solutions}

Standard uranium solutions were prepared from weighed amounts of New Brunswick Laboratory standard uranium oxide $\left(\mathrm{U}_{3} \mathrm{O}_{8}\right)$. The oxide was dissolved in nitric acid and 


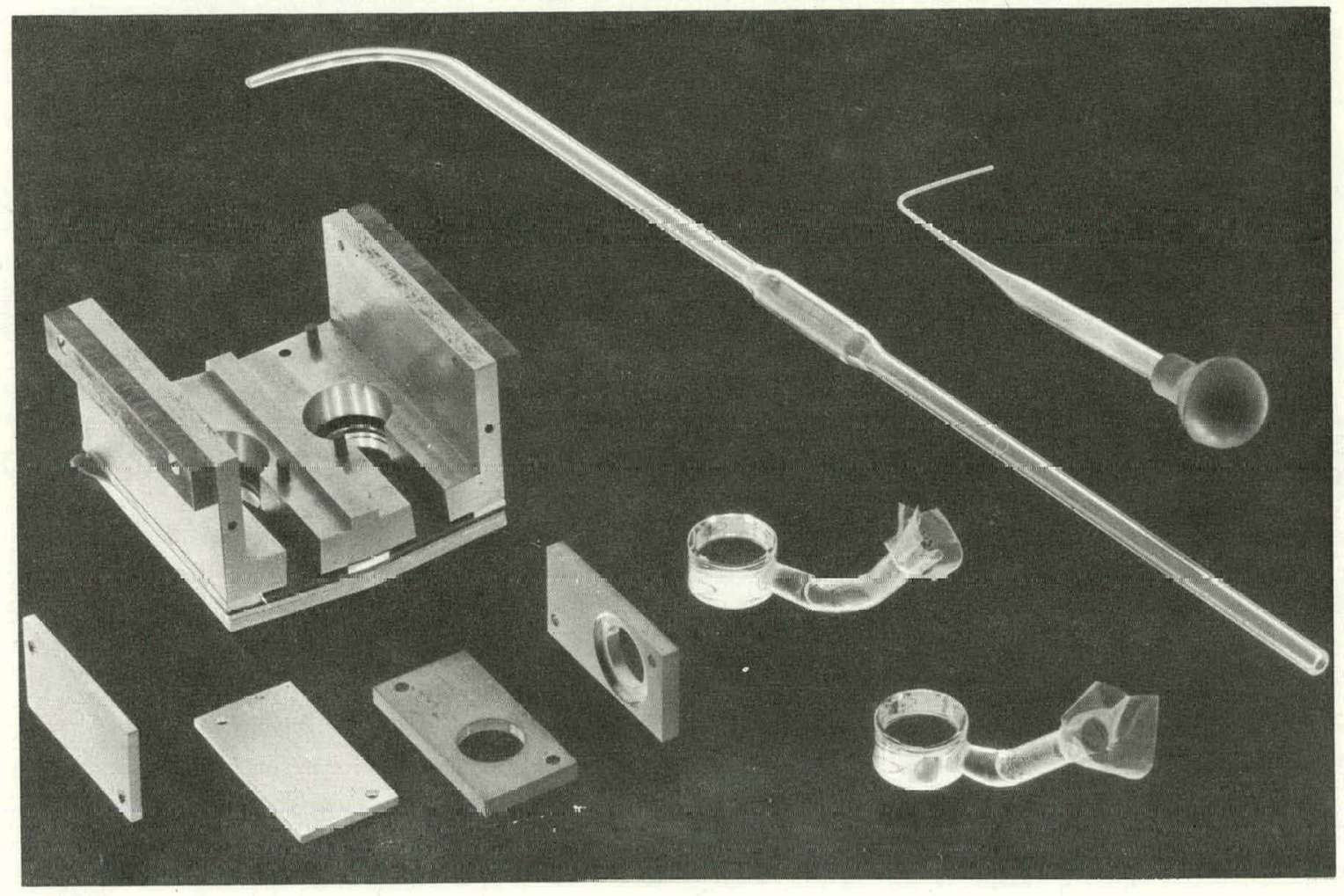

Fig. 1 - X-ray photometer cells and aluminum plates 
diluted to a suitable volume to yield a uranium stock solution. Actual sample solutions were prepared by evaporating aliquots of the stock solution nearly to dryness and diluting with water to a desired weight in tare glass weighing bottles. The uranium concentration was expressed in milligrams of $\mathrm{UO}_{2}$ per gram of solution.

Operation of the Instrument

The X-ray photometer was allowed to warm up for about 1 hour before absorption readings were made. Readings were taken after insertion of the sample by setting the $X$-ray high-voltage primary at 80 volts and the $X$-ray filament current at 115 milliamperes.

\section{INITIAL RESULTS}

Among others, Bartlett ${ }^{2}$ has reported that "frequent recalibration was found necessary because of changes in response of the instrument." Preliminary work at ANYD obtained by using three settings and three dial readings at each setting verified his conclusions. Some results on succeeding days varied 3 percent in terms of uranium concentration. In order to determine whether accuracy could be increased by the proper combination and number of settings and readings, nine standard solutions were prepared. For each solution five readings at each of $\mathbf{3 0}$ different settings, a total of 2700 readings, were made by two operators. The results indicated that a standard curve obtained on one day under these conditions must not be used the following day. The results did indicate, however, that instrument response was relatively constant during any one day. It was believed that if aluminum plates could be used as pseudo-uranium standards, their use would be more desirable than frequent preparation of standard uranium solutions and the uncertainty of their stability with time.

\section{ALUMINUM-PLATE METHOD}

Two aluminum plates 0.092 and 0.113 inch thick were prepared. These plates were machined so that their surfaces were as nearly parallel as possible, and notched so that they would fit reproducibly in the sample holder. Their "uranium equivalences" were then determined. These values are shown in Table 1. Two operators, each using a different cell for the standard solution but the same reference cell, obtained five attenuation readings at each of six different settings on four standard uranium solutions and on the two aluminum plates.

The data in Table 1, when plotted, yield almost a straight line, inasmuch as the uranium concentration range is not very great. Consequently, the data from the four standard uranium solutions were used to obtain the equation of this line by the method of least squares. The corresponding uranium equivalence values for the two aluminum blocks were then obtained by appropriate substitution into these equations. These values are shown in Table 2.

It can be seen that the uranium equivalences of the aluminum plates remain constant even though instrument response varies from day to day. It can also be seen that the uranium equivalences are strongly dependent upon the characteristics of the sample solution cells used in their determination. The cells used were from a matched pair prepared for spectrophotometric work. Althuugh two cells may yield the same uranium equivalence value at one concentration, the same value may not necessarily be obtained at other concentrations, as evidenced by the data obtained on the fourth day. Examination of six pairs of matched cells indicated that no two cells were interchangeable. Therefore, sample analyses must be performed with the same cell used for the aluminum-plate calibration. 
TABLE 1

X-RAY PHOTOMETER READINGS OBTAINED IN THE DETERMNNATION OF URANIUM EQUIVALENCES OF ALUMINUM PLATES

\begin{tabular}{|c|c|c|c|c|c|c|c|c|}
\hline \multirow{4}{*}{$\begin{array}{l}\text { Uranium Concentration, } \\
\text { mgUO }_{2} \text { per g solution }\end{array}$} & \multicolumn{8}{|c|}{$\mathrm{X}$-Ray Photometer Readings } \\
\hline & \multicolumn{6}{|c|}{ Operator } & \multirow[b]{2}{*}{ I } & \multirow[b]{2}{*}{ II } \\
\hline & I & II & I & Cell & I & II & & \\
\hline & 470 & 562 & 470 & 562 & 470 & 562 & 470 & 466 \\
\hline 23.99 & 326.2 & & & & & & & \\
\hline 24.97 & 343.4 & & & & & & & \\
\hline 27.22 & 387.0 & & & & & & & \\
\hline 27.95 & 402.6 & & & & & & & \\
\hline $\mathrm{Al}_{92}$ & 323.5 & & & & & & & \\
\hline $\mathrm{Al}_{113}$ & 42.1 .6 & & & & & & & \\
\hline 24.00 & & 296.2 & 324.2 & 296.1 & 323.7 & 297.6 & 326.1 & 326.7 \\
\hline 25.01 & & 317.4 & 343.1 & 316.4 & 343.7 & 316.7 & $345: 4$ & 345.6 \\
\hline 26.99 & . & 353.9 & 382.3 & 353.3 & 382.4 & 354.0 & 383.9 & 385.2 \\
\hline 27.97 & & 373.8 & 401.4 & 372.7 & 401.5 & 373.6 & 402.9 & 404.4 \\
\hline $\mathrm{Al}_{92}$ & & 300.4 & 322.4 & 299.9 & 322.2 & 299.9 & 323.3 & 323.5 \\
\hline $\mathrm{Al}_{113}$ & & 400.0 & 420.0 & 398.4 & 421.3 & 398.7 & 421.8 & 420.9 \\
\hline
\end{tabular}

TABLE 2

URANIUM EQUIVALENCES OF ALUMINUM PLATFS

\begin{tabular}{ccccc}
\hline Day & Operator & Cell No. & \multicolumn{2}{c}{$\begin{array}{c}\text { Uranium Equivalence, } \\
\mathrm{mg} \mathrm{UO}_{2} \text { per g solution }\end{array}$} \\
\cline { 3 - 5 } & & & $\mathrm{Al}_{92}$ Plate & $\mathrm{Al}_{113}$ Plate \\
\hline 1 & I & 470 & 23.90 & 28.98 \\
1 & II & 562 & 24.18 & 29.33 \\
2 & I & 470 & 23.93 & 28.93 \\
2 & II & 562 & 24.18 & 29.32 \\
3 & I & 470 & 23.92 & 28.98 \\
3 & II & 562 & 24.13 & 29.31 \\
4 & I & 470 & 23.86 & 28.95 \\
4 & II & 466 & 23.86 & 28.81 \\
& & Avg $^{a}$ & 23.90 & 28.96 \\
\hline
\end{tabular}

a Average of operator I data only.

By use of aluminum plates as standards the concentrations of uranium in the standard solutions were then recalculated, and it was found that quite accurate results were obtained. The limit of error on a single sample at the 95 percent confidence level (three settings, five readings at each setting) was found to be \pm 0.245 percent and \pm 0.177 percent on duplicates.

Thus, in the determination of uranium in solution by $X$-ray absorption with aluminum plates as standards, it has been found that accurate analytical work may be performed, that only a minimum amount of time is necessary for daily calibration, and that this calibration can be perfor med easily and without complication. 


\section{References}

1. Aborn, R. H., and Brown, R. H., Ind. Eng. Chem., Anal. Ed. 1, 26 (1929).

2. Rartlett., T. W., Anal. Chem. 23, 701 (1951).

3. Lambert, M. C., "Absorption of Polychromatic X-rays as a Function of Atomic Number and Source Voltage," AEC Project Report HW-30190, December 14, 1953.

4. Liebhafsky, H. A., Smith, H. M., Tanis, H. E., and Winslow, E. R., Pacific Northwest Regional Meeting of Am. Chem. Soc., Richland, Washington, June 1950.

5. Sullivan, M. V., and Frieđman, H., Ind. Eng. Chem., Anal. Ed. 18, 304 (1946).

6. Vollmar, R. C., Petterson, E. E., and Petruzzelli, P. A., Anal. Chem. 21, 1491 (1949). 